\title{
Shading of River Channels as an Important Factor Reducing Macrophyte Biodiversity
}

\author{
Szymon Jusik*, Ryszard Staniszewski \\ Faculty of Environmental Engineering and Spatial Management, Department of Ecology \\ and Environmental Protection, Poznań University of Life Sciences, Poland
}

Received: 18 September 2017

Accepted: 23 December 2017

\begin{abstract}
Studies of the impact of river shading on biological diversity of aquatic plants were carried out in central and western parts of the Polish Lowlands. Data was collected during field surveys in 2003 to 2010. Studied rivers represented watercourses with small and average watershed areas according to the Water Framework Directive, and sand was the dominant substrate of the river bottom. To evaluate the impact of shading on aquatic plants, biodiversity metrics such as number of taxa, Shannon-Wiener index, Simpson index, and evenness index were used. For statistical analyses, pairs of studied sites were compared and it was found that increased shading was limiting biodiversity, enhancing growth of bryophytes, and had minor influence on macrophyte indices describing ecological status. In the case of most of the diversity indices, high statistical significance was observed for pairs of sites with greater differences of shading between each other.
\end{abstract}

Keywords: macrophytes, lowland rivers, shading, biodiversity

\section{Introduction}

Light is a key driving factor of life in river ecosystems. Strong shadowing of river channels limits the development of aquatic plants, their abundance, and biodiversity [1]. Increased sunlight penetration generally enhances the vegetation biomass, plant cover, and biological diversity [2-3]. In the case of photophobic species, excessive sunlight can lead to limiting shoot elongation and slowing down biomass development [4]. On the other hand, a decrease of sunlight caused by emergent macrophytes can lead to a reduction in the number of phytoplanktonic organisms in lowland rivers [5]. Changes in aquatic plant cover caused by limitation

*e-mail: jusz@up.poznan.pl of light penetration can affect spatial variability and characteristics of river channel sediments, which are modified by the presence of vascular plants [6].

Some submerged macrophytes, e.g., Myriophyllum spicatum, can dominate the subsurface water layer under shading conditions due to rapid elongation to sites with better light intensity [7-9], observed higher retention of nutrients (especially ammonia and nitrogen) in shaded river sections thanks to the accumulation in macrophytes biomass. Besides impact on light and nutrient conditions in waters, macrophytes have also proven to carry out allelopathic activities in relation to different groups of organisms, which simultaneously can strongly modify aquatic species structure [10-11].

Jusik and Szoszkiewicz [12] observed significant correlations between the level of morphological 
modifications and overshadow of lowland river channels. Together with the increase of modifications of watercourses, the rate of shadow was decreasing due to the changes of land use and simplification of the riparian species structure, commonly related to regulation works. In sites localised on natural or seminatural rivers (Habitat Modification Score, $\mathrm{HMS} \leq 8$ ), the level of shadow varied from $45 \%$ to $70 \%$, while on sites moderately modified $(8<\mathrm{HMS} \leq 44)$ it dropped to $20-50 \%$. In strongly modified river sites (HMS $>44$ ), the level of shadow was low and ranged from $5 \%$ to $15 \%$. Hachoł and Bondar-Nowakowska [13] found that the approach to riverside management, connected with the rate of human pressure, influence the macrophyte species structure. The effect of construction works on macrophytes depends on their scope [14]. During the planning of river conservation or regulation works, it is crucial to maintain proper light conditions for macrophytes due to the possible problems with both absence and limitation of aquatic plant development [15]. Excess light, which can cause even full overgrowth of the river channel, thus changes water flow conditions [16] and causes a decrease in channel permeability [17]. The phenomenon of river channel overgrowth is very intensive in lowland rivers flowing through agricultural areas [18], where the presence of strong sunlight conditions (lack of trees, removed during regulation works) and significant input of nutrients due to the surface flow are present simultaneously [17].

Macrophytes are an important group of aquatic organisms and in regard to the water framework directive (WFD) are widely used to assess water quality and the ecological state of rivers in the EU [3, 19-22]. The presence and coverage of aquatic plants in waters can be utilised as data for calculating macrophyte indices [23-24].

The main goal of these studies was to estimate the relationship between the shaded area of a river site and the diversity of aquatic vegetation. Shading is one of many factors affecting macrophytes in rivers. Therefore, when studying this issue, it is very important to eliminate the variability of other environmental factors that may be a potential source of error. In our study, all environmental variables in addition to shading were similar in all studied rivers. In addition, the study was conducted in pairs of river sections, differing only in shading and directly adjacent to each other. In this paper, the impact of shading was evaluated both for indices of ecological status and for macrophyte biodiversity. Dividing pairs of river sections into four groups was a unique statistical approach that enabled us to better evaluate the role of shading in shaping biodiversity of macrophytes under different shading conditions. The new and poorly explained impact question of shading the river channel on assessment of ecological status was studied. This is an important issue for river monitoring and for selecting the right location for field research.

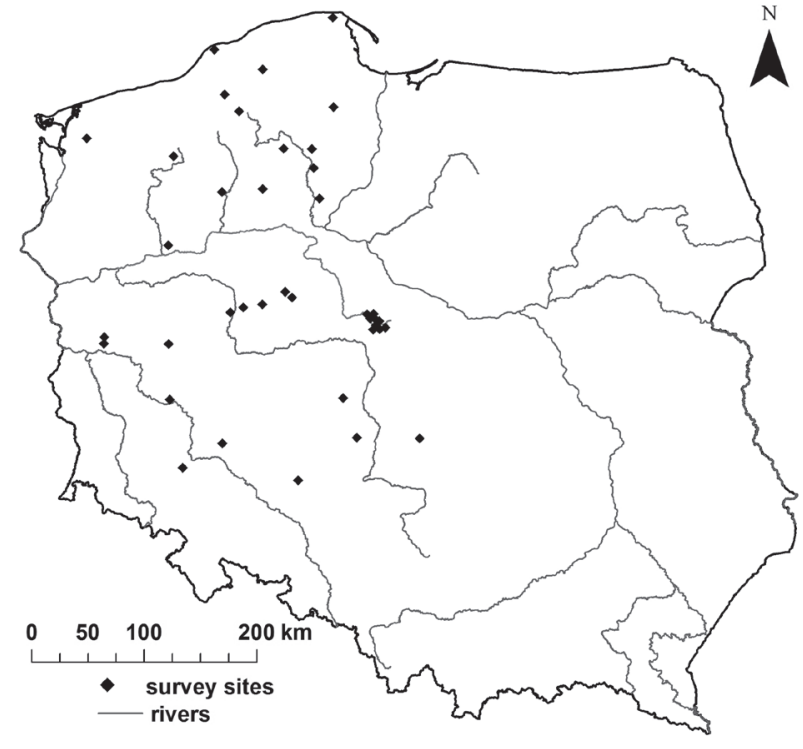

Fig. 1. Sketch map of surveyed sites.

\section{Materials and Methods}

\section{Field Surveys}

The field studies were carried out at the peak of the growing season (July-August) in 2003-2010. In total, 40 pairs of river sites were surveyed (Fig. 1). Analysed pairs of river sites were divided into four groups differing in shading caused by trees and bank shrubs (Figs 2, 3). Shading was defined as a vertical plan of tree canopies on the water surface (approximately the shading of river water surface at noon) and estimation accuracy of river shading was equal to $5 \%$ of each surveyed river site. The purpose of this segregation of river sites was to check whether the macrophyte response was based solely on the level of

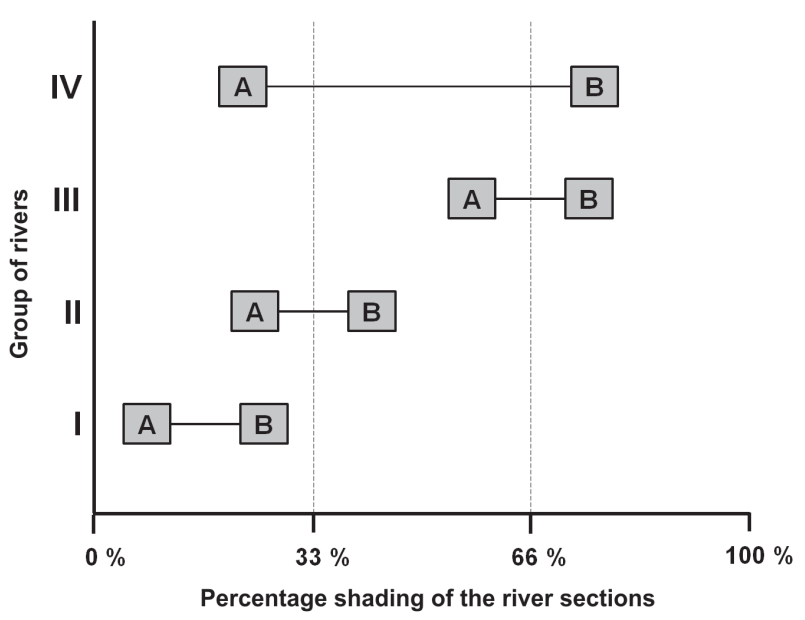

Fig. 2. Diagram of the experiment: A-B - pairs of related (adjoining) river sections, $\mathrm{A}$ - less shaded sections, $\mathrm{B}$ - more shaded sections. 
I)

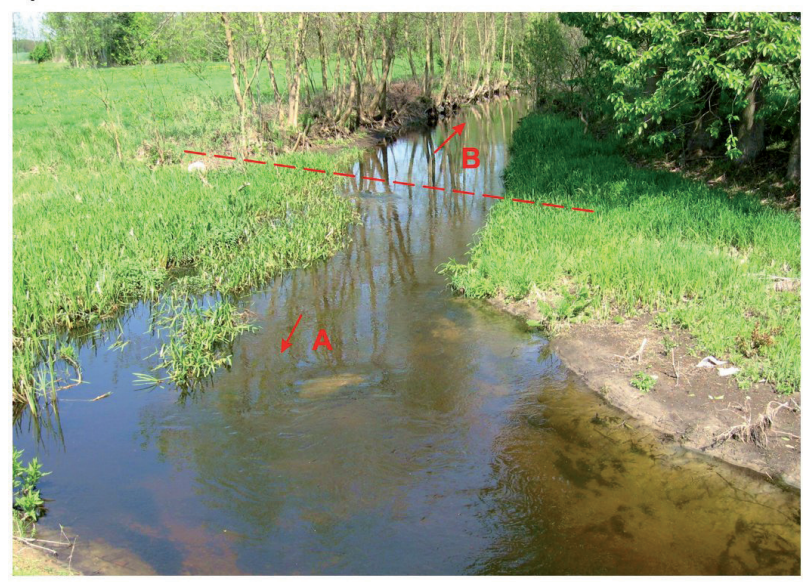

II)

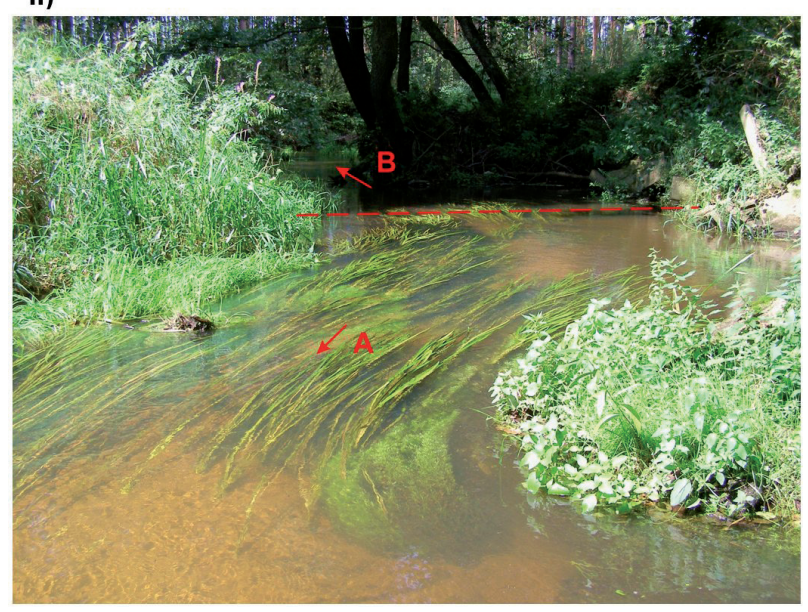

Fig. 3. Examples of pairs of river sections: A - less shaded sections, B - more shaded sections; I) Noteć, Marcjanki, N52 ${ }^{\circ} 5^{\prime} 02.4^{\prime \prime}, \mathrm{E} 18^{\circ} 35^{\prime} 00.3$ ', group II (fot. R. Staniszewski, 30.05.2011); II) Czerska Struga, Łosiny, N53 44'18.2”, E1756' 08.1”, group IV (fot. S. Jusik, 21.08.2007).

shading or also on the difference in shading between the sites within the pair.

The studied rivers were similar in terms of water depth and width, flow type, river bottom substrate, and water quality parameters. In all sites representing small and average rivers (catchment area $40-450 \mathrm{~km}^{2}$, water width 2.5-7.5 m, water depth 0.3-0.8 m) sand was a dominant bottom substrate (with silt and gravel in smaller amounts), smooth or ripple flow type.

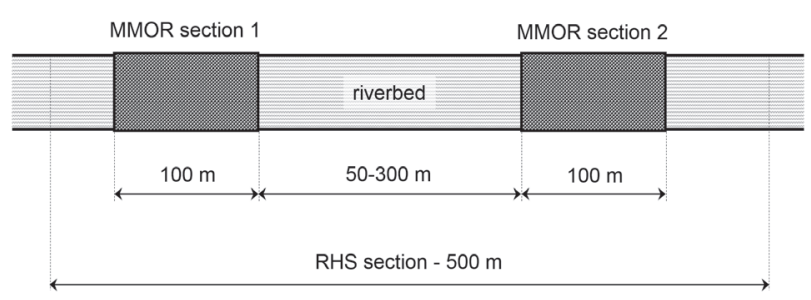

Fig. 4. Scheme of distribution in river two macrophyte sections (MMOR) within the RHS section.
The hydromorphological evaluation was conducted according to the river habitat survey (RHS) method [25], which gathers data from 500-m stretches of rivers. Two numerical metrics based on the RHS protocol were produced. High values of the habitat quality assessment (HQA) indicate an extensive presence of a number of natural river features and high landscape diversity along a river. High values of the habitat modification score (HMS) indicate an extensive anthropogenic alteration, such as bank and channel resection, reinforcement, or other river engineering construction projects [25].

The macrophyte survey, including two sections (a pair of related river sections), was located inside each of the RHS sites (Fig. 4). Field surveys were conducted using the macrophyte method for river assessment (MMOR) [26]. The macrophyte survey was conducted along river reaches of $100 \mathrm{~m}$ in length. Only river macrophytes growing in the water were recorded. The survey includes a list of species and estimated vegetation cover. The presence of each species was recorded with their percentage cover using the following nine-point scale: $<0.1 \%, 0.1-1 \%, 1-2.5 \%, 2.5-5 \%, 5-10 \%$, $10-25 \%, 25-50 \%, 50-75 \%$, and $>75 \%$ [26]. Both sections of MMOR were contained in one RHS site and varied only according to shadow rate (Fig. 2). Other habitat conditions (physico-chemical parameters of water, hydromorphological conditions, hydrology, bottom substrate) were similar within the RHS section. Thanks to this uniformity, the evaluation of the impact of shadow on macrophyte biodiversity was possible. Both macrophyte-related sections, differing in the degree of shading within one RHS section, were tested the same day by the same person.

Water samples for the physico-chemical analysis were collected during the same field surveys when botanical and hydromorphological surveys were carried out. Surface water samples were taken mid-stream below the surface. All samples were filtered using Sartorius cellulose filters with a nominal pore size of $0.45 \mu \mathrm{m}$, except for those used for determining total phosphorus. Water samples were cooled and analysed in a laboratory within a 12-h period. Electrical conductivity and $\mathrm{pH}$ were measured by digital potentiometers (Elmetron CP-401, CC-551). Concentrations of phosphate (molybdenum blue method), total phosphorus (molybdenum blue method after mineralisation in an open system), and nitrate nitrogen (cadmium reduction method) were determined using a spectrophotometer Hach-Lange DR/2400.

\section{Mathematical and Statistical Procedures}

Based on the collected data, as many as 9 biodiversity metrics were calculated: total number of taxa, number of species of macroalgae, bryophytes, vascular hydrophytes and vascular helophytes, Shannon-Wiener diversity index, evenness, Simpson diversity index, 
and total vegetation cover. Next, the contribution of four groups of plants was analysed (i.e., macroalgae, aquatic bryophytes, hydrophytes, and helophytes). Furthermore, three macrophyte indices of ecological status were computed: (1) Polish Marophyte Index for Rivers, MIR [26]; (2) French Indice Biologique Macrophytique en Rivie're, IBMR [27]; and (3) British River Macrophyte Nutrient Index, RMNI [28]. These indices reflect river degradation, especially eutrophication level (concentration of phosphate and total nitrogen).

To evaluate the homogeneity of the four analysed groups according to physico-chemical and hydromorphological parameters, a variance analysis was made. The analysis was preceded by estimating normal distribution of data using the Shapiro-Wilk $\mathrm{W}$ test. This test showed that, in the case of three parameters (phosphates, total phosphorus, nitrates), distribution of data is significantly right-skewed and therefore nonparametric Kruskal-Wallis variance analysis was used to evaluate the homogeneity of the groups. The influence of shading on macrophyte diversity and ecological state were estimated using the Wilcoxon $\mathrm{Z}$ test for the related pairs of observations. The choice of nonparametric test as an alternative for t-Student test was due to the significant rightskewed distribution of data for several parameters (number of macroalgae and aquatic mosses taxa and its cover contribution) and lack of proper transformations to obtain normal distribution. In the next step, statistical analyses were utilised to find relationships between particular macrophyte species cover and the rate of shadow conditions using Spearman's rank correlation. Only macrophytes with five or more appearances in different sites were used in the analyses.

\section{Results and Discussion}

\section{Similarity of Abiotic Conditions in the Studied Rivers}

The four analysed group of rivers were very similar in terms to physico-chemical parameters of water and hydromorphological conditions, thus Kruskal-Wallis ANOVA did not show any statistically significant differences among groups $(\mathrm{H}<5, \mathrm{p}>0.05)$. The first group was characterised by higher nutrient concentrations in water and a bigger rate of modifications, but these differences were not statistically significant (Table 1). In general, all studied river sections represented high conductivity, high concentrations of phosphates, and nitrates in water as well as large hydromorphological modifications.

The four analysed groups of rivers were different only in terms of the level of shading (Table 2, Fig. 2). In Group I, the shading difference was equal to $26.2 \%$ on average (less shaded sections average $2.4 \%$ and more shaded sections average $28.7 \%$ ). In Group II, the difference in shade was equal to $27.7 \%$ on average (less shaded sections average $25.1 \%$ and more shaded sections average $52.8 \%$ ). In group III, the shading difference was equal to $25.0 \%$ on average (slightly less shaded sections average $50.6 \%$ and more shaded sections average 75.6\%). In contrast, in Group IV the shading difference was higher and was equal to $58.3 \%$ on average (within pairs of less shaded sections they average $16.9 \%$ and more shaded sections average $75.2 \%$ ).

\section{The Impact of Shading on Macrophyte Biodiversity}

Using the Wilcoxon test for associated pairs of river sites allows the elimination of influence on macrophytes

Table 1. Variability ranges (min-max) and median of physico-chemical parameters of water and hydromorphological indices in four analysed river groups.

\begin{tabular}{|c|c|c|c|c|c|}
\hline \multirow{2}{*}{ Parameter } & \multirow{2}{*}{ Units } & \multicolumn{4}{|c|}{ Group of rivers } \\
\hline & & $\mathrm{I}$ & II & III & IV \\
\hline \multicolumn{6}{|c|}{ Physico-chemical parameters } \\
\hline $\mathrm{pH}$ & - & $7.33-8.24(7.68)$ & $7.12-8.16(7.76)$ & $7.20-8.17(7.66)$ & $7.01-8.18(7.82)$ \\
\hline Conductivity & $\mu \mathrm{S} \cdot \mathrm{cm}^{-1}$ & $378-1750(778)$ & $305-1387(611)$ & $285-1399(574)$ & $328-1338(695)$ \\
\hline Phosphates & $\mathrm{mg} \mathrm{PO}_{4}^{3-\cdot} \cdot \mathrm{dm}^{-3}$ & $0.19-1.33(0.42)$ & $0.14-1.35(0.32)$ & $0.08-0.82(0.28)$ & $0.07-1.35(0.45)$ \\
\hline Total phosphorus & $\mathrm{mg} P \cdot \mathrm{dm}^{-3}$ & $0.10-1.09(0.62)$ & $0.10-0.59(0.43)$ & $0.07-0.47(0.35)$ & $0.05-0.91(0.50)$ \\
\hline Nitrates & $\mathrm{mg} \mathrm{N}-\mathrm{NO}_{3} \cdot \mathrm{dm}^{-3}$ & $0.02-2.60(0.66)$ & $0.04-1.88(0.44)$ & $0.01-1.45(0.43)$ & $0.01-2.14(0.49)$ \\
\hline \multicolumn{6}{|c|}{ Hydromorphological indices } \\
\hline $\mathrm{HQA}^{1}$ & Quantitive (0-100) & $35-64(45)$ & $38-68(52)$ & $36-71(51)$ & $33-68(49)$ \\
\hline HMS $^{2}$ & Quantitive (0-100) & $0-90(41)$ & $0-65(28)$ & $0-91(26)$ & $0-76(32)$ \\
\hline
\end{tabular}

${ }^{1} \mathrm{HQA}$ - Habitat Quality Assessment [25]

${ }^{2} \mathrm{HMS}$ - Habitat Modification Score [25] 
Table 2. Level of shading river channel in four analysed river groups (see Figs 2 and 3).

\begin{tabular}{|c|c|c|c|c|}
\hline \multirow{2}{*}{ Group of rivers } & \multirow{2}{*}{$\begin{array}{c}\text { Number of pairs } \\
\text { of river sections }\end{array}$} & $\begin{array}{c}\text { Difference in shading between } \\
\text { adjacent sections }\end{array}$ & $\begin{array}{c}\text { Shading of the less } \\
\text { shaded section (A) }\end{array}$ & $\begin{array}{c}\text { Shading of the more } \\
\text { shaded section (B) }\end{array}$ \\
\cline { 3 - 5 } & 9 & 26.2 & 2.4 & 28.7 \\
\hline I & 10 & 27.7 & 25.1 & 52.8 \\
\hline II & 10 & 25.0 & 50.6 & 75.6 \\
\hline III & 11 & 58.3 & 16.9 & 75.2 \\
\hline IV & & & & \\
\hline
\end{tabular}

by environmental factors other than shading. In the case of 9 studied variables, a lack of statistically significant differences were found. For two variables (total cover and cover of hydrophytes), significant differences were observed Krved in the four analysed groups (Table 3). The highest number of significant variations were found in group IV, where strong differences in shading were observed in pairs of sites (approximately $60 \%$ ). In this group of pairs, sites with higher shading had a significantly smaller number of taxa, number of helophytes, total cover $(p<0.005)$, cover of macroalgae, hydrophytes, Shannon-Wiener index $(\mathrm{p}<0.05)$, and cover of helophytes $(\mathrm{p}<0.01)$.
During these studies, a limitation of macrophyte cover area and number of taxa were found, especially for pairs represented by group IV and to some extent also group III. Similarly, in surveys undertaken by Kohler [29], the limitation of macrophyte biomass with shading conditions exceeding $55 \%$ of the area corresponded with results presented in this paper. In contrast, the number of species and abundance of mosses was higher when the shaded area was larger. Such a phenomenon was also observed in studies carried out by Vieira [30].

On the basis of the obtained results, it was found that shading of the river channel is limiting the number of macrophyte taxa, especially emerged plants (helophytes)

Table 3. Results of Wilcoxon signed-rank test $(Z)$ in four analysed river groups.

\begin{tabular}{|c|c|c|c|c|}
\hline \multirow{2}{*}{ Variables } & \multicolumn{4}{|c|}{ Group of rivers } \\
\hline & I & II & III & IV \\
\hline Number of taxa & 0.210 & 1.599 & $1.960 *$ & $2.942 * * *$ \\
\hline Number of macroalgae & 0.447 & 0.802 & 0.085 & 1.079 \\
\hline Number of bryophytes & 1.604 & 0.365 & 1.604 & 0.365 \\
\hline Number of hydrophytes & 0.085 & 1.859 & 1.183 & 1.944 \\
\hline Number of helophytes & 0.770 & 0.948 & $2.666 * *$ & $3.059 * * *$ \\
\hline Total cover & $2.192 *$ & $2.701 * *$ & $2.772 * *$ & $2.903 * * *$ \\
\hline Cover of macroalgae & 0.944 & 0.802 & 1.859 & $1.992 *$ \\
\hline Cover of bryophytes & 1.604 & 0.365 & 0.524 & 0.730 \\
\hline Cover of hydrophytes & $2.073 *$ & $2.090^{*}$ & $2.039 * *$ & $2.134 *$ \\
\hline Cover of helophytes & 0.533 & 1.070 & 1.244 & $2.667 * *$ \\
\hline Shannon-Wiener diversity index & 0.059 & 0.357 & 1.718 & $2.040 *$ \\
\hline Evenness index & 0.178 & 1.070 & 0.889 & 1.020 \\
\hline Simpson diversity index & 0.059 & 0.255 & 1.481 & 1.020 \\
\hline $\mathrm{MIR}^{1}$ & 0.415 & 1.070 & 1.125 & 0.392 \\
\hline IBMR $^{2}$ & 0.178 & 1.497 & 0.980 & 0.628 \\
\hline $\mathrm{RMNI}^{3}$ & 1.244 & 0.459 & 0.652 & 0.314 \\
\hline
\end{tabular}

${ }^{1}$ MIR - Polish Marophyte Index for Rivers [26]

${ }^{2}$ IBMR - French Indice Biologique Macrophytique en Rivie're [27]

${ }^{3}$ RMNI - British River Macrophyte Nutrient Index [28]

Values in bold statistically significant: ${ }^{*}-\mathrm{p}<0.05, * *_{-} \mathrm{p}<0.01, * * *{ }_{-} \mathrm{p}<0.005$. 

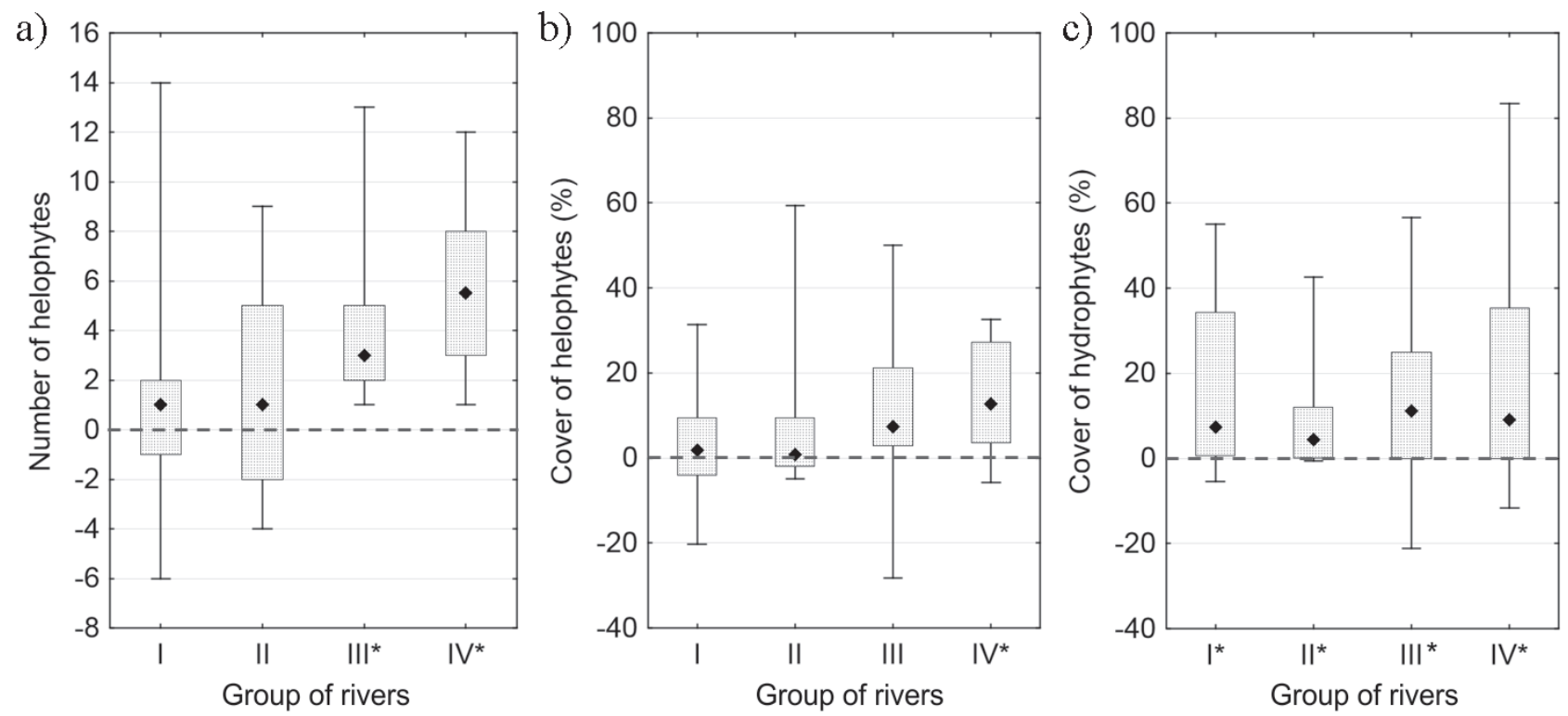

Fig. 5. Comparison of results of Wilcoxon test (median \pm quartiles \pm min-max) - differences between the values of sections less and more shaded: a) number of helophytes, b) cover of helophytes, c) cover of hydrophytes

* statistically significant difference $(\mathrm{p}<0.05)$.

growing on river banks. This leads to a decrease of Shannon-Wiener index coefficient. Shading also causes a limitation of macrophyte cover of all studied groups except aquatic mosses (Table 3, Fig. 5). Earlier studies showed that according to the ecology of rivers, optimal shading level of the water table is about $80 \%$ [31]. Under conditions with shading level below $50 \%$ of the area, the increase of macrophyte biomass can be rapid and reach $300 \mathrm{~g}$ of dry mass per square meter, above this level of biomass the cutting of aquatic plants is generally recommended.

\section{The Impact of Shading on Macrophyte Species}

Due to the typical lowland character of the surveyed rivers (laminar current, silty bottom substrate) vascular plants were the dominant taxa, with particular contributions by Lemna minor L. (66\% of sites), Agrostis stolonifera L. (58\%), Mentha aquatica L. (56\%), Phalaris arundinacea L. (55\%), Berula erecta (HuDs.) Coville (50\%), Myosotis palustris (L.) L. EMEND. RCHB. (49\%), and Sparganium emersum Rehmann (41\%). All mentioned species are perceived as very common in the eutrophic Polish Lowlands waters. Similar species were identified by Hachol and Bondar-Nowakowska [15] in small and average watercourses of Lower Silesia, where the domination of Sparganium emersum, Phalaris arundinacea, and Lemna minor was observed. Also, Wiegleb [32] found similar taxa in lowland rivers of northwestern Germany, such as Phalaris arundinacea ( $80 \%$ of sites), Callitriche platycarpa KüтZ. (58\%), Sparganium emersum (56\%), Lemna minor (54\%), Myosotis palustris (53\%), and Agrostis stolonifera $(47 \%)$.
The most common taxa among bryophytes were Leptodictyum riparium (Hedw.) WARNST. (18\% of sites), Fontinalis antipyretica Hedw. (13\%), Platyhypnidium riparioides (HEDw.) Dixon (10\%), Brachythecium rivulare Sснімp. (10\%), Cratoneuron filicinum (Hedw.) SPruce (10\%), Conocephalum conicum (L.) Dumort. (10\%), and Hygroamblystegium tenax (Hedw.) JENn. $(8 \%)$. Other mosses were observed only in single river sites.

Shadow level in river channels had statistically significant relationships only with the cover of four species of macrophytes $(p<0.05)$. Positive correlation with the rate of shadowing was found in the case of two aquatic bryophyte species: Hygroamblystegium tenax $(\mathrm{r}=0.766, \mathrm{~N}=8)$ and Fontinalis antipyretica $(\mathrm{r}=0.716$, $\mathrm{N}=10$ ), which showed greater cover when the shadow rate was higher. Such a relationship can be the indirect effect of a strong linkage of mosses with the presence of trees and bushes growing along the river. Roots of trees and woody debris are the most important place for development of bryophytes in lowland watercourses [30]. Negative correlation with rate of shadow was found in the case of two vascular species: Ceratophyllum submersum L. $(\mathrm{r}=-0.973, \mathrm{~N}=7)$ and Sagitaria sagittifolia $\mathrm{L} .(\mathrm{r}=-0.745, \mathrm{~N}=16)$, which showed a decrease of cover when the shadow in the river channel was greater.

The importance of shading for macrophyte diversity was observed in earlier studies, where cutting of trees and shrubs growing on river banks was used in restoration of rivers [33]. Such a method was utilised in Słupia Valley Landscape Park on Kwacza River, and a significant increase of diversity and cover of macrophytes was observed [34]. Additionally, species characteristic of habitat 3260 (natural and semi-natural 
watercourses with floating vegetation of the Ranunculion fluitantis alliance) appeared [35], such as Batrachium aquatile (L.) DumORT. and Callitriche cophocarpa SENDTN. from the Ranunculion fluitantis community.

A common procedure during river conservation is cutting trees and shrubs along a river site. This solution is used to obtain uniformity of bank profiles and to reduce the number of objects affecting hydraulic roughness under flood conditions. At the same time, shading of the river channel prevents watercourses from macrophyte overgrowth and thus reduces the frequency of necessary weed cutting [18, 33]. A similar process was observed in studied sites with strong shading of river channels where the increased presence of bryophytes and subsequent decrease of macrophytes were observed [30].

\section{The Impact of Shading on Macrophyte Indices of Ecological Status}

The impact of shading a river channel on results of ecological status evaluated using macrophytes (MIR, RMNI, and IBMR indices) was tested. Properly developed indices based on bioindicative properties of organisms used in the estimation of trophic degradation should be independent of the rate of shading. Studies have shown that the level of shading does not significantly affect the results of macrophyte indices $(p>0.05)$, despite a reduction of macrophyte biodiversity (Table 3). During our studies, it was found that strong river shadowing $(>60 \%)$ causes a decrease in the number of macrophyte taxa in river sites, from on to six on average (Fig. 5), and this could limit the accuracy of evaluation of the ecological status of the river. Authors of macrophyte methods define the minimum number of indicative species as five, thus enhancing proper evaluation of ecological status [26]. In extreme cases, high shadowing can preclude accurate evaluation. For instance, in four analysed pairs in river sites with high rates of shadowing, the number of identified taxa was below five.

\section{Conclusions}

1) The impact of shading on macrophyte indices of ecological status was negligible regardless of the degree of shading, but in extreme cases high shadowing can preclude accurate evaluation due to the small number of indicator species.

2) Although increased shading was limiting macrophyte biodiversity and total cover in the studied rivers, in the case of bryophytes, both cover and number of species were higher in shaded sites.

3) For all analysed indices, higher statistical significance was observed for pairs of sites with greater shading difference.

4) A slight increase in shading of the riverbed (about $25 \%$ ) results in a reduction in the coverage of macrophytes, including primarily submerged plants, but has little impact on biodiversity indicators.

5) The shading limit value, which causes a clear reaction of macrophytes, is about $50 \%$.

6) Obtained results can be utilised both in control and enhancement of macrophyte growth in rivers.

\section{Acknowledgements}

The authors are deeply indebted to the anonymous reviewers for their valuable suggestions and comments on this manuscript. This research was funded by the Ministry of Science and Higher Education (contract Nos. N 304099 31/3546 and N N305 3637 33).

\section{Conflict of Interest}

The authors declare no conflict of interest.

\section{References}

1. ALI M.M., HASSAN S.A., SHAHEEN A.S.M. Impact of riparian trees shade on aquatic plant abundance in conservation islands. Acta Botanica Croatica, 70, 245, 2011.

2. SENDER J. The effect of riparian forest shade on the structural characteristics of macrophytes in a mid-forest lake. Applied Ecology and Environmental Research, 14 (3), 249, 2016.

3. SZOSZKIEWICZ K., ZBIERSKA J., STANISZEWSKI R., JUSIK S. The variability of macrophyte metrics used in river monitoring. Oceanological and Hydrobiological Studies, 38 (4), 117, 2009.

4. WERSAL R.M., MADSEN J.D. Influences of light intensity variations on growth characteristics of Myriophyllum aquaticum. Journal of Freshwater Ecology, 28 (2), 147, 2013.

5. GOŁDYN R., SZELĄG-WASIELEWSKA E. The effects of two shallow reservoirs on the phyto- and bacterioplankton of lowland river. Polish Journal of Environmental Studies, 14 (4), 437, 2005.

6. PEDERSEN M.L., BAATRUP-PEDERSEN A., ROTH F.R., MADSEN T.V., LARSEN S.E. Short-term impacts of weed cutting on physical habitats in lowland rivers the importance of initial environmental conditions. Polish Journal of Environmental Studies, 20 (5), 1271, 2011.

7. LU J., WANG Z., XING W., LIU G. Effects of substrate and shading on the growth of two submerged macrophytes. Hydrobiologia, 700, 157, 2013.

8. ZEFFERMAN E. Increasing canopy shading reduces growth but not establishment of Elodea nuttallii and Myriophyllum spicatum in stream channels. Hydrobiologia, 734, 159, 2014.

9. WILCOCK R.J., SCARSBROOK M.R., COOKE J.G., COSTLEY K.J., NAGELS J.W. Shade and flow effects on ammonia retention in macrophyte-rich streams: implications for water quality. Environmental Pollution, 132 (1), 95, 2004.

10. WANG H., LIANG F., ZHANG L. Composition of anticyanobacterial activity of essential oils from six different 
submerged macrophytes. Polish Journal of Environmental Studies, 24 (1), 333, 2015.

11. ZHANG S., GUO L., CAO J., CHANG J. Allelopathic activities of three emergent macrophytes on several monospecific cyanobacterial species and natural phytoplankton assemblages. Polish Journal of Environmental Studies, 24 (1), 397, 2015.

12. JUSIK S., SZOSZKIEWICZ K. Biodiversity of water plants in diverse conditions of morphological modifications in lowland rivers of western Poland. Nauka Przyroda Technologie, 3 (3), \#84, 2009 [In Polish].

13. HACHOŁ J., BONDAR-NOWAKOWSKA E. Influence of ways of the riverine area management on the aquatic vascular plants. Infrastruktura i Ekologia Terenów Wiejskich 2 (3), 719, 2014 [In Polish].

14. HACHOE J., BONDAR-NOWAKOWSKA E. An assessment of the ecological status of diverse watercourses of Lower Silesia, Poland. Polish Journal of Environmental Studies, 21 (1), 75, 2012.

15. HACHOŁ J., BONDAR-NOWAKOWSKA E. Hierarchy of stream bed system elements interactions on aquatic plants. Acta Scientiarum Polonorum Formatio Circumiectus, 14 (3), 55, 2015 [In Polish].

16. KAŁUŻA T. The influence of the trees and bushes shadow on the changes of flow conditions in the lowland watercourse. Acta Scientiarum Polonorum Formatio Circumiectus, 14 (4), 29, 2015 [In Polish].

17. DAWSON F.H. The reduction of light as a technique for the control of aquatic plants an assessment. Proceedings of the Association of Applied Biologists Symposium Aquatic Weeds and their Control, Oxford, 157, 1981.

18. BURRELL T.K., O'BRIEN M., GRAHAM S.E., SIMON K.S., HARDING J.S., MCINTOSH A.R. Riparian shading mitigates stream eutrophication in agricultural catchments. Freshwater Science, 33, 73, 2014

19. BIRK S., WILLBY N. Towards harmonization of ecological quality classification: Establishing common grounds in European macrophyte assessment for rivers. Hydrobiologia, 652, 149, 2010.

20. STANISZEWSKI R., JUSIK S. Impact of mine waters discharge from open-pit lignite mine on river water quality. Rocznik Ochrona Środowiska, 15 (3), 2652, 2013 [In Polish].

21. GEBLER D., KAYZER D., SZOSZKIEWICZ K., BUDKA A. Artificial neural network modelling of macrophyte indices based on physico-chemical characteristics of water. Hydrobiologia, 737, 215, 2014.

22. WIEGLEB G., GEBLER D., VAN DE WEYER K., BIRK S. Comparative test of ecological assessment methods of lowland streams based on long-term monitoring data of macrophytes. Science of the Total Environment, 541, 1269, 2016.

23. SZOSZKIEWICZ K., JUSIK S., ZGOŁA T., CZECHOWSKA M., HRYC B. Uncertainty of macrophyte-based monitoring for different types of lowland rivers. Belgian Journal of Botany, 140, 7, 2007.

24. BIRK S., WILLBY N.J., KELLY M.G., BONNE W., BORJA A., POIKANE S., VAN DE BUND W.
Intercalibrating classifications of ecological status: Europe's quest for common management objectives for aquatic ecosystems. Science of the Total Environment, 454-455, 490, 2013.

25. SZOSZKIEWICZ K., ZGOŁA T., JUSIK S., HRYCJUSIK B., DAWSON F.H., RAVEN P. Hydromorphological assessment of flowing waters. A manual for field studies according to the River Habitat Survey in Poland. Bogucki Wydawnictwo Naukowe, Poznań-Warrington, 2012 [In Polish].

26. SZOSZKIEWICZ K., ZBIERSKA J., JUSIK S., ZGOŁA T. Macrophyte Method for River Assessment. A methodological manual on the assessment and classification of the ecological status of flowing waters based on aquatic plants. Bogucki Wydawnictwo Naukowe, Poznań, 2010 [In Polish].

27. HAURY J., PELTRE M.C., TREMOLIERES M., BARBE J., THIEBAUT G., BERNEZ I., DANIEL H., CHATENET P., HAAN-ARCHIPOF G., MULLER S., DUTARTRE A., LAPLACE-TREYTURE C., CAZAUBON A., LAMBERT-SERVIEN E. A new method to assess water trophy and organic pollution - the Macrophyte Biological Index for Rivers (IBMR): its application to different types of river and pollution. Hydrobiologia, 570, 153, 2006.

28. WILLBY N., PITT J.-A., PHILLIPS G. The ecological classification of UK rivers using aquatic macrophytes. UK Environment Agency Science Reports. Project SC010080/ SR1. Environmental Agency, Bristol, 2009.

29. KOHLER J., HACHOE J., HILT S. Regulations of submerged macrophyte biomass in a temperate lowland river: Interactions between shading by bank vegetation, epiphyton and water turbidity. Aquatic Botany, 92, 129, 2010.

30. VIEIRA C., SENECA A., SERGIO C., FERREIRA M.T. Bryophyte taxonomic and functional groups as indicators of fine scale ecological gradients in mountain streams. Ecological Indicators, 18, 98, 2012.

31. MANDER U., MATT O., NUGIN U. Perspectives on vegetated shoals, ponds, and ditches as extensive outdoor systems of wastewater treatment in Estonia. In: Etnier C., Guterstam B. (Eds.), Ecological engineering for wastewater treatment. $2^{\text {nd }}$ edition, CRC Press, 1997.

32. WIEGLEB G., HERR B., ZANDER B., BRÖRING U., BRUX H., VAN DE WEYER K. Natural variation of macrophyte vegetation of lowland streams at the regional level. Limnologica, 51, 53, 2015.

33. ŻELAZO J., POPEK Z. Basics of river renaturation. Wydawnictwo SGGW, Warszawa, 2014 [In Polish].

34. OBOLEWSKI K., OSADOWSKI Z., MILLER M. Renaturation methods for small river basins in the example of the Kwacza River (Słupia River basin). Nauka Przyroda Technologie, 3 (3), \#95, 2009 [In Polish].

35. LEYSSEN A., DENYS L., SCHEIDERS A., MOUTON A.M. Distribution and environmental requirements of stream habitat with Ranunculion fluitantis and CallitrichoBatrachion vegetation in lower Belgium (Flanders). Aquatic Conservation: Marine and Freshwater Ecosystems, 24, 601, 2014. 